\title{
Vigilantes da moral e dos bons costumes: condições sociais e culturais para a estruturação política da censura durante a ditadura militar
}

Adrianna Cristina Lopes Setemy*

\section{RESUMO}

Considerando a censura como parte de uma cultura da vigilância à liberdade de expressão, o artigo pretende demonstrar que, além de um eficaz instrumento de violação, quando se trata de defender a moral e os bons costumes, a censura consiste em um instrumento político de legitimação perante setores da sociedade civil, um endosso do Estado àquilo que é considerado pertinente aos valores da família cristã. A discussão será feita a partir da análise das condiçôes sociais e culturais em que se deu o processo de estruturaçáo política e institucionalização da censura de publicações consideradas ofensivas à moral e aos bons costumes durante a ditadura militar. O objetivo do artigo é contribuir com os estudos sobre as estratégias de poder e os comportamentos sociais diante do autoritarismo, a fim de compreender as bases sociais de sustentação do poder autoritário.

Palavras-chave: censura; legitimidade; moral; bons costumes.

\section{ABSTRACT}

Considering censorship as part of a culture of surveillance of free speech, the article intends to demonstrate that besides being an effective instrument of violation when it comes to defending moral values and good manners, censorship consists of a political instrument of legitimacy before certain sectors of civil society, an endorsement on the part of the State to what is considered relevant to the values of the Christian family. The discussion will be based on the analysis of the social and cultural conditions that contributed to the development of the process of political structuring and institutionalization of censorship of publications considered offensive to moral values and good manners during the Brazilian military dictatorship. The purpose of this article is to contribute to the study of power strategies and social behaviors in the face of authoritarianism, in order to understand the social bases of authoritarian power.

Keywords: censorship; legitimacy; moral values; good manners. 
VIGILANTES DA MORAL E DOS BONS COSTUMES: CONDIÇÕES SOCIAIS E CULTURAIS PARA A ESTRUTURAÇÃO POLÍTICA DA CENSURA DURANTE A DITADURA MILITAR

Adrianna Cristina Lopes Setemy

\section{RESUMEN}

Considerando la censura como parte de una cultura de vigilancia a la libertad de expresión, el artículo pretende demostrar que más allá de un eficaz instrumento de violación, cuando se trata de defender la moral y las buenas costumbres, la censura consiste en un instrumento político de legitimación ante sectores de la sociedad civil, un endoso del Estado a aquello que es considerado pertinente a los valores de la familia cristiana. La discusión será hecha a partir del análisis de las condiciones sociales y culturales en las que ocurrió el proceso de estructuración política e institucionalización de la censura de publicaciones consideradas ofensivas a la moral y a las buenas costumbres durante la dictadura militar en Brasil. El objetivo del artículo es contribuir con los estudios sobre las estrategias de poder y los comportamientos sociales ante el autoritarismo, a fin de comprender las bases sociales de sustentación del poder autoritario.

Palabras clave: censura; legitimidad; moral; buenas costumbres.

Em 2016, enquanto visitava a primeira exposição dedicada aos desenhos do jornalista, humorista, dramaturgo e tradutor Millôr Fernandes, um episódio chamou atenção: a demissão de Millôr dos Diários Associados, em outubro de 1963, em decorrência dos desenhos e do texto de "A verdadeira história do paraíso", publicados no Pif-Paf, seção que fez parte da revista O Cruzeiro entre 1945 e 1963.

"A verdadeira história do paraíso" já havia sido encenada no teatro e apresentada pelos canais de tevê do Rio de Janeiro e de Belo Horizonte quando foi vendida como matéria especial para O Cruzeiro e publicada na ediçáo de 3 de outubro de 1963.

A maneira como o público recebeu a publicação de "A verdadeira história do paraíso", bem como as consequências que se abateram sobre Millôr pela publicação, podem ser indiciadas a partir do texto intitulado "EXPLICAÇÃO" (em letras garrafais) com que os editores abriram a edição de $O$ Cruzeiro do dia 19 de outubro de 1963:

Existe uma consciência individual e uma consciência coletiva. A sociedade comete erros como tal. Do mesmo modo, uma empresa jornalística. 'O Cruzeiro' cometeu um erro. Falhou na vigilância à liberdade de escrever que tradicionalmente concede a seus colaboradores. Os sinceros protestos que começam a chegar à Redação contra a publicação de matéria considerada insultuosa às convicçôes religiosas do povo brasileiro, que são as nossas, foram precedidos do nosso próprio sentimento de culpa. Ao permitir que em nossas páginas fôssemos nós mesmos agravados de forma táo brutal. Náo cabe aqui, propriamente, um pedido de desculpas. Isso seria fácil, mas de nada adiantaria. Apenas queremos dar aos nossos leitores, aos milhóes 
VIGILANTES DA MORAL E DOS BONS COSTUMES: CONDIÇÓES SOCIAIS E CULTURAIS PARA A ESTRUTURAÇÃO POLÍTICA DA CENSURA DURANTE A DITADURA MILITAR

Adrianna Cristina Lopes Setemy

de brasileiros que se orientam pela doutrina cristã, uma informação: esses fatos não mais se repetirão em 'O Cruzeiro'. Estaremos mais vigilantes, principalmente sobre a seção que provocou os justos protestos dos nossos leitores: 'O Pif-Paf'.

Cometemos uma falta. Confiamos na honestidade intelectual de quem há mais de uma década assumiu conosco e com os leitores de 'O Cruzeiro' o compromisso de criar um humor inteligente e sadio. Aqui nos penitenciamos.

Resta-nos dizer que esta explicação seria desnecessária se não fosse imperiosa. Sentimo-nos tão ofendidos em nossa sensibilidade quanto os nossos leitores de todos os recantos do País. Em três décadas, desde que foi fundada, esta Revista, feita com amor para nossos leitores, sempre procurou dar, com autenticidade, seu testemunho de cristianismo, mais, muito mais do que apenas crença em Deus. É perante Deus que nos penitenciamos.

A DIREÇÃO ${ }^{1}$

As palavras em negrito no texto falam de vigilância à liberdade de escrever como uma atribuição dos diretores de $O$ Cruzeiro, que "vigilantes" e zelosos acabaram imediatamente com a seção Pif-Paf e demitiram Millôr, em atenção às demandas dos leitores da revista. Os vestígios não deixam dúvidas: Millôr foi vítima de sanção à sua liberdade de expressão. Pode-se falar que Millôr foi vítima de censura, considerando que, à época dos acontecimentos relatados o Brasil vivia em pleno regime democrático e progressista, como se pode caracterizar o governo de João Goulart?

Segundo Robert Darnton, a definição de censura é bastante ampla e abarca todo tipo de sanção, legais ou ilegais, emanadas de autoridades do Estado, de instituições privadas, de grupos de colegas, professores, ou seja, pode abranger quase tudo. Entretanto, o autor adverte: identificar a censura com coerçóes de todo tipo é trivializá-la. ${ }^{2}$

O autor aponta uma tendência geral na maneira como a censura vem sendo estudada durante os últimos anos: de um lado, a história da luta entre os que buscavam liberdade de expressão e as autoridades políticas e religiosas na tentativa de reprimi-los; de outro, o relato sobre coerçóes de todo tipo que inibiam a comunicação e a liberdade de expressão. ${ }^{3}$

De acordo com essa tendência geral identificada por Robert Darnton, a historiografia da censura de imprensa durante a ditadura militar brasileira conta com muitos estudos que tratam o tema de maneira geral e interligada ao estabelecimento, fortalecimento e desmonte de um Estado autoritário ao longo dos anos de 1964 a 1985. ${ }^{4}$ Daí resulta a concepção da

\footnotetext{
${ }^{1}$ A verdadeira história do paraíso. O Cruzeiro. Rio de Janeiro: Diários Associados, p. 64-73. Disponível em: $<$ http://memoria.bn.br/DocReader/DocReader.aspx?bib=003581\&PagFis=145716\&Pesq=>. Acesso em: 12 maio 2017.

2 DARNTON, Robert. Censores em ação: Como os estados influenciaram a literatura. São Paulo: Companhia das Letras, 2016, p. 10-11.

${ }^{3}$ Ibidem, p. 15.

${ }^{4}$ Dois exemplos de obras que trataram de questóes gerais sobre a censura são a coletânea de artigos organizada por Maria Luiza Tucci Carneiro e o trabalho que resultou da organização do acervo Miroel Silveira, coordenado
} 
VIGILANTES DA MORAL E DOS BONS COSTUMES: CONDIÇÓES SOCIAIS E CULTURAIS PARA A ESTRUTURAÇÁO POLÍTICA DA CENSURA DURANTE A DITADURA MILITAR

Adrianna Cristina Lopes Setemy

censura como instrumento de controle e coerção da imprensa, empregado arbitrariamente pela ditadura a fim de garantir a ordem social e a organização do poder pelo controle da circulação de ideias e informações.

Maria Luiza Tucci Carneiro, no texto de abertura da coletânea Minorias silenciadas: história da censura no Brasil, definiu a censura como um dos mais poderosos instrumentos de dominação da ditadura militar pós-64:

Temiam-se os homens de vasta cultura, autores de livros, jornalistas e tipógrafos. Professores e estudantes de ciências humanas e ciências políticas também incomodavam. Temiam-se as críticas ao regime, as denúncias, as passeatas estudantis, o humor dos caricaturistas, os enredos cinematográficos e teatrais. Temiam-se os homens com passado de militante político, razão pela qual o regime militar pós-64 instituiu os corriqueiros "atestados de antecedentes políticos”. Tudo contava, até a posse de um único livro. Regredimos aos tempos medievais. Livros foram queimados, intelectuais fichados e torturados.

Constatamos que, no decorrer do tempo, as histórias e estórias se repetem. O Estado republicano, censor por excelência, foi responsável pela mutilação da cultura nacional, interferindo, negativamente, na construção do conceito de cidadania. O aparato policial, organizado durante décadas e que perseguiu os "homens de ideias", deve ser considerado como um dos promotores da barbárie, da violência, da segregação e da intolerância, marcas registradas do século XX. O Estado tem aqui sua responsabilidade como gerenciador e legitimador da brutalidade, promotor do medo e da autocensura. ${ }^{5}$

Entretanto, o caso de Millôr Fernandes indica que, antes mesmo do golpe militar e da instalação de uma longa ditadura, setores da sociedade estiveram empenhados na vigilância à liberdade de escrever, especialmente no que dizia respeito a temas morais, o que evidencia um traço de continuidade entre dois períodos geralmente caracterizados em termos de ruptura: democracia e ditadura.

Este artigo irá abordar um problema que, em geral, os estudos sobre censura de imprensa durante a ditadura militar não levaram em conta: além de ser um instrumento de violação do direito de liberdade de expressão, quando se tratava de defender a moral e os bons costumes

por Cristina Costa. Ver, respectivamente: CARNEIRO, Maria Luiza Tucci (Org.) Minorias silenciadas: a história da censura no Brasil. São Paulo: Edusp/Imprensa Oficial do Estado/Fapesp, 2002; COSTA, Cristina. Censura em cena: teatro e censura no Brasil. São Paulo: Edusp/Fapesp/Imprensa Oficial, 2006. Dentre os trabalhos que se dedicaram a analisar as particularidades da censura de imprensa destacam-se os seguintes: MARCONI, Paolo. A censura politica na imprensa brasileira (1968-1978). 2. ed. São Paulo: Global, 1980; KUCINSKI, Bernardo. Jornalistas e revolucionários nos tempos da imprensa alternativa. São Paulo: Scritta, 1991; AQUINO, Maria Aparecida de. Censura, imprensa e estado autoritário (1968-1978): o exercício cotidiano da dominação e da resistência: O Estado de São Paulo e Movimento. Bauru: Edusc, 1999; SMITH, Anne-Marie. Um acordo forçado: o consentimento da imprensa à censura no Brasil. Rio de Janeiro: FGV, 2000.

${ }_{5}^{5}$ CARNEIRO, Maria Luiza Tucci. Minorias silenciadas: história da censura no Brasil, op. cit., p. 21-22. 
VIGILANTES DA MORAL E DOS BONS COSTUMES: CONDIÇÓES SOCIAIS E CULTURAIS PARA A ESTRUTURAÇÃO POLÍTICA DA CENSURA DURANTE A DITADURA MILITAR

a censura consistiu em um instrumento político legítimo perante setores da sociedade civil, um endosso do Estado àquilo que era considerado pertinente aos valores da família cristá. Embora a coerção à liberdade de expressão, tendo em vista a defesa da moral e dos bons costumes, esteja presente na sociedade brasileira independentemente da vigência de um regime autoritário, foi durante os anos da ditadura militar que se estruturou e institucionalizou uma censura a publicaçóes consideradas obscenas e que ameaçavam destruir náo apenas os valores morais da sociedade brasileira, mas também a segurança nacional.

A censura, segundo Darnton, seria um ingrediente da realidade social que permeia a psique individual e a mentalidade coletiva em toda parte e em qualquer época, tão onipresente no campo social que dificilmente poderia ser distinguida de um instrumento de coerção, propriamente dito, a serviço dos interesses do Estado. ${ }^{6}$ Entretanto, essa visão excessivamente "relativa" da censura precisa, segundo o autor, ser conciliada com uma análise "normativa" da prática que, em última instância, consiste na ação do Estado a partir de múltiplos agentes (censores, policiais, juízes, Ministério Público) para impor sançôes contra a livre circulação de ideias.

É nesse sentido que a primeira parte do artigo irá discutir a censura de imprensa a partir de uma perspectiva mais ampla, segundo a qual durante a ditadura militar a censura de imprensa não se resumiu a uma batalha entre forças paralelas, mas, em parte, resultou do que se pode denominar como uma cultura da vigilância à liberdade de expressão, já inscrita na tradição paternalista da política brasileira, segundo a qual compete ao Estado, por meio do seu poder de polícia, a missão de controlar a sociedade, garantir a paz, a segurança, a ordem e a preservação dos modos de vida da coletividade, em defesa do bem comum. A censura de temas morais na imprensa consistiu em um dos instrumentos desse poder de polícia do Estado e deveria ser aplicado, dentro de limitaçóes estabelecidas por normas legais, no intuito de conter a "onda de pornografia e subversão" que ameaçava invadir o Brasil, especialmente por intermédio dos meios de comunicação de massa. ${ }^{7}$

Portanto, entende-se que, além de instrumento de repressão, a censura de temas morais foi um dos mecanismos empregados pela ditadura militar na busca de legitimidade perante a sociedade. De acordo com uma tradição do pensamento político ligada a autores como Maquiavel, Weber e Gramsci, a legitimidade é um atributo do Estado, alcançado à medida que há um consenso entre uma parcela significativa da população, capaz de transformar a obediência, resultante do uso da força, em adesão, que pressupóe o reconhecimento da legitimidade. ${ }^{8}$

Discutidas as condições sociais e culturais em que a ditadura militar se instalou a partir do golpe de 1964, será apresentada uma descrição de como o cerceamento à liberdade de imprensa foi sendo, aos poucos, estruturado e normatizado como um mecanismo para ex-

\footnotetext{
${ }^{6}$ DARNTON, Robert. Censores em ação: como os estados influenciaram a literatura, op. cit., p. 13.

${ }^{7}$ ROSA, F. A. Miranda. Sociologia do direito: o fenômeno jurídico como fato social. 6. ed. Rio de Janeiro: Zahar, 1978, p. 209-210.

${ }^{8}$ LEVI, Lucio. "Legitimidade”. In: BOBBIO, Norberto; MATTEUCCI, Nicola; PASQUINO, Gianfranco. Dicionário de política, 12. ed. Tradução de João Ferreira. Brasília: UNB, 1993, 2v., p. 674.
} 
purgar dos meios impressos aquilo que era considerado ofensa à moral e aos bons costumes, sem deixar de atender aos interesses políticos do regime.

A discussão proposta neste artigo tem causado polêmica, pois se por um lado não há dúvidas de que os militares se empenharam em controlar a discussão de temas políticos na imprensa por vê-la como um espaço fértil para contestaçóes e formação de opiniôes contrárias aos seus atos de exceção, por outro lado, a censura de temas morais e comportamentais ainda é entendida como "desculpa" para a censura de temas políticos. Beatriz Kushnir, por exemplo, afirma: "Sob a capa do 'resguardo à moral e aos bons costumes' ou defendendo questôes de 'interesse da nação', considero a censura sempre política." Entretanto, o estudo de documentos ostensivos produzidos pela ditadura, desde 1964, e da documentação produzida no âmbito da Divisão de Censura de Diversóes Públicas (DCDP) e da Divisão de Segurança e Informaçóes do Ministério da Justiça (DSI/MJ) ao longo dos anos 1970 demonstra a permanente preocupação da ditadura em controlar publicações e exteriorizaçôes contrárias à moral e aos bons costumes, inicialmente caracterizadas como forma de "abuso no exercício e liberdade de manifestação do pensamento e informação" 10 e posteriormente proibidas "por estimularem a licença, insinuar o amor livre e ameaçar destruir os valores morais da sociedade brasileira" obedecendo a um plano subversivo, que, acreditava-se, colocava em risco a segurança nacional. ${ }^{11}$

A ideia é contribuir com os estudos sobre as estratégias de poder e de legitimação da ditadura brasileira, e igualmente com as pesquisas dedicadas aos comportamentos sociais diante do autoritarismo, afim de compreender as bases sociais de sustentação do poder autoritário. ${ }^{12}$

\section{Cultura da vigilância, anticomunismo e a ditadura que se legitimou pela defesa da moral e dos bons costumes}

Ao longo do século XX, o perigo comunista tornou-se uma espécie de espectro rondando a sociedade capitalista sem respeitar limites territoriais ou culturais, como havia definido Karl Marx ainda no século XIX. A ascensão dos bolcheviques ao poder na Rússia, a partir da Revolução de outubro de 1917, causou um impacto muito forte em todo o mundo: o entusiasmo e a esperança dos revolucionários, somados à crise da sociedade liberal que se seguiu ao fim da Primeira Guerra Mundial, provocaram considerável crescimento da influência dos ideais comunistas em diferentes partes. Daí em diante, especialmente no período

\footnotetext{
${ }^{9}$ Ibidem, p. 38.

${ }^{10}$ BRASIL. Lei n. 5.250, de 9 de fevereiro de 1967.

${ }^{11}$ BRASIL. Decreto-lei n. 1.077, de 26 de janeiro de 1970.

${ }^{12}$ Autores como Rodrigo Patto, Daniel Aarão Reis, Denise Rollemberg e Janaína Cordeiro, cujos trabalhos estão citados na bibliografia, têm se dedicado a pesquisar o mito sobre a resistência e o fenômeno do apoio e do consentimento aos Estados ditatoriais.
} 
VIGILANTES DA MORAL E DOS BONS COSTUMES: CONDIÇÓES SOCIAIS E CULTURAIS PARA A ESTRUTURAÇÁO POLÍTICA DA CENSURA DURANTE A DITADURA MILITAR

compreendido entre a Revolução Russa e a crise do socialismo real na virada da década de 1980 para 1990, o comunismo tornou-se efetivamente muito mais que um "fantasma" e foi adquirindo um poder sem precedentes. Tendo sua força consubstanciada na expansão e pulverizaçáo de partidos e movimentos que cultivaram adeptos e entusiastas por toda a parte, simultaneamente engendrou sua outra face ao causar medo e insegurança nos setores mais conservadores da sociedade que, atemorizados por aquela "ameaça", apressaram-se em organizar e articular uma contraofensiva, o anticomunismo. Entre 1961 e 1964, o anticomunismo adquiriu um novo fôlego por razóes tanto endógenas como exógenas. O impacto da Revolução Cubana lançou a América Latina para o centro da Guerra Fria e estimulou tanto ação de comunistas como de anticomunistas. No Brasil, o movimento ascendente das organizaçôes de esquerda, marcado pela reestruturação do Partido Comunista Brasileiro (PCB) após crises e cisóes decorrentes da sua desestalinização, pelo surgimento de novas organizaçóes como a Ação Popular (AP), as Ligas Camponesas e a Política Operária (POLOP), e pela adesão de novos contingentes sociais ao campo esquerdista, tais como a igreja e os meios estudantis, convergiram com as mudanças processadas no quadro internacional e resultou na fagulha detonadora do golpe de 1964. A ideia de que o país corria o risco de ser invadido e dominado pela ideologia comunista constituiu-se na principal justificativa para a derrubada do presidente João Goulart, em abril de 1964, e posteriormente, ao longo do regime militar, para a construçáo do aparato repressivo do qual fazia parte a censura. ${ }^{13}$

No contexto da Guerra Fria, aqueles valores e temores se tornaram, acima de tudo, questáo de segurança nacional e foram instrumentalizados pelos grupos que estavam no poder no intuito de criar uma espécie de "histeria" dentro da sociedade, a fim de que obedecessem às determinações do Estado em relação aos mais variados aspectos da vida pública e privada. Entretanto, não se deve enfatizar apenas a dimensão "oportunista" dessa luta, já que o "perigo vermelho" era uma realidade naquele momento e foi combatido por grupos e indivíduos que viam o mundo pela ótica do anticomunismo, segundo a qual, a família, o casamento, a juventude e os valores da cristandade encontravam-se fortemente ameaçados. ${ }^{14}$

Antes do golpe de 1964, as "Marchas da Família, com Deus pela Liberdade", majoritariamente organizadas e conduzidas pelo clero e por entidades femininas compostas por mulheres da classe média, se traduziram em importantes atos de defesa intransigente de rigorosos valores morais, que estavam sendo colocados em jogo tanto pela suposta "ameaça comunista", representada na figura de João Goulart, como pelas transformaçóes que se operavam nos padrôes comportamentais, especialmente no que se referia à sexualidade e à organização da instituição familiar. Passado o golpe, essas mesmas mulheres, as chamadas "marchadeiras", deram continuidade à sua "cruzada" em defesa da moral e dos bons costumes, tendo em mente salvar a

\footnotetext{
${ }^{13}$ MOTTA, Rodrigo Patto Sá. O anticomunismo militar. In: 1964-2004: 40 anos do golpe. Ditadura militar e resistência no Brasil. Rio de Janeiro: 7 Letras, 2004, p. 292.

${ }^{14}$ Ibidem, p. 290-305, 290-291.
} 
VIGILANTES DA MORAL E DOS BONS COSTUMES: CONDIÇÓES SOCIAIS E CULTURAIS PARA A ESTRUTURAÇÃO POLÍTICA DA CENSURA DURANTE A DITADURA MILITAR

Adrianna Cristina Lopes Setemy

sociedade brasileira dos abusos introduzidos pelas novelas, filmes, músicas e publicaçôes, que aumentavam em número a cada dia, devido ao crescimento vertiginoso da indústria de bens culturais e ao desenvolvimento dos meios de comunicação de massa. ${ }^{15}$

Outra atuação marcante nesse sentido foi a da Sociedade Brasileira de Defesa da Tradição, Família e Propriedade (TFP), associação civil de âmbito nacional, composta apenas por militantes do sexo masculino e cujos objetivos eram combater a vaga do socialismo e do comunismo e ressaltar, a partir da filosofia de São Tomás de Aquino e das encíclicas, os valores positivos da ordem natural, particularmente a tradição, a família e a propriedade. Essa organização foi fundada em 1960 por Plínio Correia de Oliveira, ex-integrante da Ação Católica Brasileira (ACB), da qual se desligou em 1943, quando a organização começou a se envolver com questôes sociais. Logo após sua fundação, caracterizou-se como a mais radical organizaçáo católica de oposição ao governo João Goulart e, entre os anos de 1961 e 1963, promoveu sua primeira campanha nacional contra a "reforma agrária socialista e confiscatória" proposta pelo presidente da república. Com o golpe de 1964 e o afastamento de Goulart, a associação colocou-se imediatamente ao lado da ditadura e em oposiçáo aos setores progressistas da Igreja Católica, no intuito de fortalecer sua campanha em oposiçáo à "comunização" do clero e da sociedade brasileira. Assim, em junho de 1966, a TFP promoveu uma coleta de assinaturas para o documento intitulado "Apelo às Autoridades Civis e Eclesiásticas em Favor da Família Brasileira", que argumentava contra um projeto de lei que havia sido enviado ao Congresso e que previa a introdução do divórcio no país. Em todas as suas frentes de ação, a TFP desenvolveu constantes campanhas em defesa da família monogâmica e indissolúvel, da propriedade privada e do ataque ao comunismo e ao socialismo. ${ }^{16}$

Açôes como as empreendidas pelas "marchadeiras" ou pelos militantes da TFP estavam amparadas em valores morais fortemente enraizados na sociedade brasileira e podem ser explicadas a partir de uma cultura política anticomunista que informava a maneira como os que militavam contra o comunismo e em "defesa das instituiçôes democráticas" viam as reformas políticas e transformaçôes sociais em curso nos anos $1960 .{ }^{17}$

${ }^{15}$ FICO, Carlos. A ditadura mostra a sua cara: imagens e memórias do período. 1964-1985. Disponível em: <www.history.umd.edu/HistoryCenter/2004-05/conf/Brazil64/papers/cficoport.pdf >. Acesso em: 3 jul. 2017. p. 35-36. A respeito das marchas, cf. PRESOT, Aline. As marchas da Família com Deus pela Liberdade. Dissertação (mestrado) - Programa de Pós-graduação em História Social, Univerisdade Federal do Rio de Janeiro, 2004; SIMÓEES, Solange de Deus. Deus, pátria e família: as mulheres no golpe de 64. Belo Horizonte: UFMG, 1983; CODATO, Adriano Nervo; OLIVEIRA, Marcus Roberto de. A marcha, o terço e o livro: catolicismo conservador e ação política na conjuntura do golpe de 1964. Revista Brasileira de História. São Paulo, v. 24, n. 47, p. 271-302, 2004; CORDEIRO, Janaína. Do golpe de 1964 ao "milagre brasileiro": A Campanha da Mulher pela Democracia (CAMDE). Ação política e imaginário coletivo. Iberoamérica Social: revista-red de estudios sociales, número especial, v. 1, p. 49-69, 2016.

${ }^{16}$ KORNIS, Monica; HEYE, Thomas Ferdinand. TFP. Dicionário histórico-biográfico brasileiro pós-1930. Disponível em: <http://www.fgv.br/cpdoc/acervo/dicionarios/verbete-tematico/sociedade-brasileira-dedefesa-da-tradicao-familia-e-propriedade>. Acesso em: 3 jul. 2017.

${ }^{17}$ Ver, a respeito das origens e dos desdobramentos do fenômeno anticomunista no Brasil, os trabalhos do historiador Rodrigo Patto Sá Motta, especialmente Em guarda contra o perigo vermelho: o anticomunismo no Brasil (1917-1964). Tese (doutorado em História Econômica) — Faculdade de Filosofia, Letras e Ciências 
VIGILANTES DA MORAL E DOS BONS COSTUMES: CONDIÇÓES SOCIAIS E CULTURAIS PARA A ESTRUTURAÇÁO POLÍTICA DA CENSURA DURANTE A DITADURA MILITAR

A partir dos anos 1960, comportamentos até entáo considerados ousados ou mesmo proibidos passaram a ser amplamente discutidos, sobretudo na imprensa, tais como a igualdade entre os sexos, a liberaçấo feminina, a homossexualidade, a virgindade, o uso de pílula anticoncepcional, a exploração do corpo e da mente por intermédio das drogas e da psicanálise, o aborto, a religiosidade, o divórcio e a loucura. A este respeito, o historiador Eric Hobsbawm fez a seguinte afirmação em sua "breve história" do século XX, "essas tendências, claro, não afetaram igualmente todas as partes do mundo (...). O que era e é muito mais interessante é que, grandes ou pequenas, as mesmas transformaçóes puderam ser identificadas por todo o globo 'modernizante"..$^{18}$

No Brasil, mesmo estando sob a vigência de um Estado autoritário, experimentaram-se as novas tendências comportamentais vindas do exterior, sobretudo das capitais da contracultura (Londres, Nova York) destacando-se os novos padróes de comportamento da juventude, o clima de relaxamento sexual, a experimentação sensorial do corpo, a "revolta lírica" dos hippies, o cinema de Godard, a música dos Beatles, as cançôes de Bob Dylan e James Joplin e a crise na relaçáo entre os gêneros e as geraçóes. ${ }^{19}$ Falar, cantar, ousar na maneira de se vestir e de se comportar se tornaram-se armas no combate à ordem estabelecida ao mesmo tempo em que se tornavam alvo de perseguição daqueles que associavam qualquer forma de contestação à ordem estabelecida como ameaça subversiva.

De acordo com a Doutrina de Segurança Nacional e Desenvolvimento, que deu os fundamentos teóricos que justificaram a intervenção e permanência dos militares na política após o golpe de 1964, o Brasil se encontrava sob a ameaça de uma guerra revolucionária de fundo ideológico e imperialista, apoiada e estimulada pelo comunismo internacional. ${ }^{20}$ Considerando que a guerra revolucionária comunista recrutava seus combatentes entre os próprios nativos do "país-alvo" por meio de sua estratégia de ação indireta e psicológica, a Doutrina via toda a população como suspeita, e os indivíduos como inimigos internos potenciais. ${ }^{21}$

Um dos tópicos da Doutrina afirmava que uma das principais armas do inimigo era a propaganda veiculada por intermédio dos meios de comunicação de massa, que se encarregaria de desencadear o processo subversivo pelo afrontamento aos valores morais, aos fundamentos da família e pela disseminação de maus hábitos, especialmente entre os jovens. De acordo com os termos da Doutrina de Segurança Nacional a "crise moral" consistia em uma estratégia subversiva do "movimento internacional comunista", que ameaçava tanto a

Humanas da USP, São Paulo, 2002; e o artigo "O anticomunismo militar", publicado nos Anais do Seminário 1964-2004: 40 anos do golpe. Ditadura militar e resistência no Brasil, op. cit.

${ }^{18}$ HOBSBAWM, Eric. Era dos extremos. O breve século XX. 1914-1991. 2. ed. Sáo Paulo: Companhia das Letras, 2000, p. 317.

${ }^{19}$ HOLLANDA, Heloísa Buarque de. Impressöes de viagem: CPC, vanguarda e desbunde, 1967/70. Rio de Janeiro: Rocco, 1992, p. 61-90.

${ }^{20}$ Manual básico da ESG. [S.1.: s.n.], 1976, p. 101.

${ }^{21}$ ALVES, Maria Helena Moreira. Estado e oposição no Brasil (1964-1984). Petrópolis, Vozes: 1985, p. 38. 
VIGILANTES DA MORAL E DOS BONS COSTUMES: CONDIÇÓES SOCIAIS E CULTURAIS PARA A ESTRUTURAÇÃO POLÍTICA DA CENSURA DURANTE A DITADURA MILITAR

Adrianna Cristina Lopes Setemy

ordem social interna quanto a segurança nacional. ${ }^{22} \mathrm{O}$ medo compartilhado pelos setores militares que ensejaram o golpe de 1964 e diferentes setores da sociedade civil de que a nação se desintegrasse a partir da infiltração de "ideologias exóticas" casou-se perfeitamente com a longa tradição de censura já existente no Brasil. ${ }^{23}$

Mesmo tendo atuado como catalisadora do golpe de $1964,{ }^{24}$ a grande imprensa esteve enquadrada pelo regime militar desde seus primeiros momentos. A despeito de algumas declaraçóes do presidente Castelo Branco quanto a sua ojeriza em relação à censura e à propaganda política e de alguns de seus biógrafos ${ }^{25}$ terem insistido em afirmar que

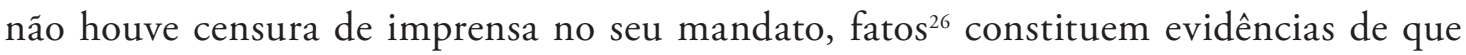
nos primeiros quatro anos do regime militar (1964-1968) a censura de temas políticos na imprensa foi aplicada quando necessária, embora de maneira episódica e acobertada. Já no que diz respeito à censura de temas morais, segundo o jornalista Elio Gaspari, quando Castelo Branco entrou no Palácio do Planalto, levou para o governo um mundo em que Jack Kerouac era visto como um "homossexual bêbado", Allen Geinsberg um "judeu doido"; Aldous Huxley um "inglês excêntrico"; Wright Mills um "exibicionista”; Herbert Marcuse um “alemão perigoso” e Martin Luther King um “ingênuo sonhador”. Todos eles, com seus respectivos pensamentos e estilos de vida, estavam muito longe da lógica do poder que havia se instalado no Brasil a partir do golpe de 1964 e figuravam como marginais em um "mundo arrumado", cujos problemas deveriam ser resolvidos por meio daquele "vagaroso processo de evolução" em que mandava quem podia e obedecia quem tinha juízo. Tratava-se, portanto, de um mundo no qual a homossexualidade era uma anomalia e a condição feminina, um estuário procriador, amoroso e doméstico. ${ }^{27}$ Assim, Gaspari entende que o regime militar brasileiro, "com suas violências e mesquinharias", caiu em meio àquela "delirante agitação" sem entendê-la, mas pensando em reprimi-la. ${ }^{28}$ Diante da "explosão anárquica” daqueles anos, a ditadura militar imbuiu-se de um "salvacionismo de quitanda" e difundiu a ideia de que possuía a "clarividência de

\footnotetext{
${ }^{22}$ Manual básico da ESG, op. cit., p. 86-101.

${ }^{23}$ Para um panorama de como se deu a implantação e o desenvolvimento da prática da censura no Brasil ao longo de sua história, cf. COSTELLA, Antonio. O controle da informação no Brasil: evolução histórica da legislação brasileira de imprensa. Petrópolis, RJ: Vozes, 1970, v. 2.

${ }^{24}$ Cf. FERREIRA, Jorge Luiz; GOMES, Angela Maria de Castro. 1964: o golpe que derrubou um presidente, pôs fim ao regime democrático e instituiu a ditadura no Brasil. Rio de Janeiro: Civilização Brasileira, 2014. ${ }^{25}$ Luís Viana Filho, autor de O governo Castelo Branco, e John W. F. Dulles, autor de Castelo Branco: o caminho para a presidência; foram dois biógrafos que procuraram destacar em suas obras o suposto caráter "legalista" e "democrático" de Castelo Branco, o que hoje vem sendo revisto pela recente historiografia acerca do regime militar.

${ }^{26}$ Um exemplo disso foi o fato de Castelo Branco ter deixado o jornalista Carlos Heitor Cony sem punição após as acusaçóes que proferiu contra ele em sua coluna no jornal O Correio da Manhã. O fato de tê-lo dispensado de puniçáo significa que dispunha de meios para puni-lo, o que denuncia a existência da censura.

${ }^{27}$ GASPARI, Elio. A ditadura envergonhada. São Paulo: Companhia das Letras, 2002, p. 215.

${ }^{28}$ Ibidem, p. 233.
} 
VIGILANTES DA MORAL E DOS BONS COSTUMES: CONDIÇÓES SOCIAIS E CULTURAIS PARA A ESTRUTURAÇÁO POLÍTICA DA CENSURA DURANTE A DITADURA MILITAR

Adrianna Cristina Lopes Setemy

se antecipar ao Juízo Final, perfilando-se à mão direita de Deus Padre como emissário de um novo tempo". ${ }^{29}$

Essa ideia está presente nas palavras do primeiro general-presidente, Castelo Branco, em uma entrevista publicada pela revista Manchete, na qual, ao falar das proibiçóes aplicadas durante seu governo, fez a seguinte afirmação:

Reconhece o atual governo que a revolução tem tido de concentrar seus esforços nas proibiçóes e na severidade com que contém hábitos perdulários e dissolutos, próprios de regimes inflacionários. Acha a situação muito semelhante à do tempo de Moisés, que nas tábuas da lei teve de redigir dez mandamentos proibitivos, no Monte Sinai, justamente porque a orgia campeava. ${ }^{30}$

Nos últimos anos, a abertura e a investigação da documentação que compóe o fundo arquivístico da DCDP e da DSI/MJ, ${ }^{31}$ que estão sob a guarda do Arquivo Nacional e foram abertos a partir de 1996, possibilitaram novas abordagens a respeito do tema da censura, que já é um clássico na historiografia da ditadura militar. Esses estudos apontaram a distinção entre duas formas de censura praticadas durante o regime militar: a censura de diversóes públicas e a censura de imprensa. ${ }^{32}$

A censura de diversóes públicas tinha, por definição, a função de fiscalizar peças de teatro, cinema, pantominas bailadas, programas de rádio e televisão, espetáculos musicais e circenses, em defesa da moralidade e dos bons costumes do "povo brasileiro". O órgão responsável por essa atividade era o SCDP, criado em 1945. A estrutura do SCDP foi inteiramente absorvida pelo regime militar, ${ }^{33}$ que ao longo da sua vigência procurou fazer algumas adaptaçôes e reestruturações que a tornassem mais consistente e mais atuante, conforme as exigências de uma indústria cultural que crescia e passava a produzir para um público de massa em escala mundial.

Se por um lado a censura de diversões públicas era antiga, legalizada e praticada por um órgão específico, por outro a censura de imprensa foi, em parte, praticada pelos agentes do Departamento de Polícia Federal por intermédio do SCDP de maneira acobertada, negada, sem ser regulamentada por um órgão específico.

\footnotetext{
${ }^{29}$ Ibidem, p. 235.

${ }^{30}$ FILHO, Murilo Melo. O que pensa Castelo. Manchete, Rio de Janeiro, n. 692, p. 18-19, 24 jul. 1965. p. 18.

${ }^{31}$ As Divisóes de Segurança e Informaçóes (DSI) foram implantadas nos Ministérios Civis em 1967, no intuito de compor uma abrangente e operante rede de espionagem. Essas repartiçóes públicas se diferenciavam das demais pela presença de militares, por sua "ânsia persecutória" de base anticomunista e pelo cuidado com as normas de sigilo. Nesse estudo pesquisei especificamente o fundo DSI/MJ, uma vez que a prática da censura estava diretamente ligada a esse ministério ou indiretamente relacionada com ele, por meio do Departamento de Polícia. ${ }^{32}$ GARCIA, Miliandre. "Ou vocês mudam ou acabam": teatro e censura na ditadura militar (1964-1985)/ Miliandre Garcia. Rio de Janeiro: UFRJ/IFCS, 2008, p. 15.

${ }^{33}$ Em 1972, o SCDP transformou-se em Divisão de Censura de Diversões Públicas (DCDP).
} 
VIGILANTES DA MORAL E DOS BONS COSTUMES: CONDIÇÓES SOCIAIS E CULTURAIS PARA A ESTRUTURAÇÁO POLÍTICA DA CENSURA DURANTE A DITADURA MILITAR

Adrianna Cristina Lopes Setemy

Entretanto, já nos primeiros anos da ditadura constituiu-se uma teia legal e conceitual que visava amparar legalmente o que, entre os anos de 1964 e 1968 foi definido como "abuso no exercício e liberdade de manifestação do pensamento e informação" ${ }^{34}$ e que a partir de 1970 passou a ser proibido com a censura de publicaçôes e exteriorizaçóes contrárias à moral e aos bons costumes. Além dos documentos excepcionais, chamados Atos Institucionais, editados entre 1964 e 1970, a Constituição de 1967, a Lei de Imprensa de 1967 e a Lei de Segurança Nacional, ${ }^{35}$ quando vistos em conjunto demonstram que a censura à imprensa foi implantada aos poucos, de acordo com uma dinâmica que combinava, simultaneamente, o recrudescimento do controle sobre a sociedade civil e a tentativa de garantir uma imagem positiva para o regime. ${ }^{36}$ A promulgaçâo do AI-5, em dezembro de 1968, significou a vitória de uma estratégia de militares e civis mais radicais para a realização de um projeto que tem suas origens ainda em $1964 .{ }^{37}$

\section{Da restrição aos "abusos da liberdade de imprensa" à estruturação da censura de publicaçóes contrárias à moral e aos bons costumes}

Desde os primeiros momentos após o golpe, os militares demonstraram grande preocupação em adotar medidas que garantissem a legitimidade da ditadura diante da sociedade. Dentre elas, destacaram-se: as alegaçóes de que somente o regime militar seria capaz de conduzir o Brasil a elevados índices de crescimento econômico e a uma situação de segurança e estabilidade nacional frente às ameaças de subversão; a manutenção, mesmo que de fachada, de instituiçôes tradicionais como o Congresso, a Constituição de 1946 e a realização de eleiçóes, atendendo, assim, à cultura política das elites que apoiaram o golpe e que viam na manutenção dessas instituiçôes um sinal de que o estado de direito seria mantido pelos militares; a alegação de que a intervenção política dos militares no Estado visava proteger

\footnotetext{
${ }^{34}$ BRASIL. Lei n. 5.250, de 9 de fevereiro de 1967.

${ }^{35}$ Por meio do Decreto n. 314, de 13 de março de 1967 a Doutrina de Segurança Nacional foi transformada em Lei de Segurança Nacional, modificada pelo Decreto-lei n. 898, de 29 de setembro de 1969. A Lei de Segurança Nacional em vigor é a Lei n. 7.170, de 14 de dezembro de 1983. Essa lei define os crimes contra a segurança nacional e estabelece regras para seu processo e julgamento. A lei vigente revogou a Lei n. 6.620, de 17 de dezembro de 1978, que havia substituído o draconiano Decreto-lei n. 898, de 29 de setembro de 1969, que, por sua vez, havia revogado o Decreto-lei n. 314, de 13 de março de 1967, primeira Lei de Segurança Nacional do regime militar que se iniciou em 1964. Ver: FRAGOSO, Heleno. Lei de Segurança Nacional. Dicionário histórico biográfico brasileiro. Disponível em: <http://www.fgv.br/cpdoc/acervo/dicionarios/ verbete-tematico/lei-de-seguranca-nacional>. Acesso em: 3 jul. 2017.

${ }^{36}$ SETEMY, Adrianna Cristina Lopes. "Em defesa da moral e dos bons costumes": censura de periódicos no regime militar. Rio de Janeiro: UFRJ/ PPGHIS, 2008.

${ }^{37}$ FICO, Carlos. 1968: o ano que terminou mal. In: ARAÚJO, Maria Paula; FICO, Carlos. 1968: 40 anos depois. História e memória. Rio de Janeiro: 7 Letras, 2009, p. 223-239.
} 
VIGILANTES DA MORAL E DOS BONS COSTUMES: CONDIÇÕES SOCIAIS E CULTURAIS PARA A ESTRUTURAÇÁO POLÍTICA DA CENSURA DURANTE A DITADURA MILITAR

Adrianna Cristina Lopes Setemy

e aperfeiçoar a democracia; e a transformação, precedida de retaliação, do sistema jurídico, mediante Atos Institucionais e Atos Complementares e Leis de Segurança Nacional. ${ }^{38}$

Logo após o golpe, o regime recém-instalado editou um documento que, posteriormente, ficou conhecido como Ato Institucional no 1 , com o objetivo de justificar as razóes da intervenção militar, expor seus objetivos e legitimar a si próprio, em detrimento do Congresso.

Embora o AI-1, ao longo de seus onze artigos, não fizesse qualquer menção à liberdade de expressáo, ela estava indiretamente garantida, uma vez que $\mathrm{o}$ ato assegurava a vigência da Constituição de 1946, de acordo com a qual, em seu art. 141, $\$ 5^{\circ}$, ficava estipulado:

$\$ 5$ o - É livre a manifestaçáo do pensamento, sem que dependa de censura, salvo quanto a espetáculos e diversôes públicas, respondendo cada um, nos casos e na forma que a lei preceituar pelos abusos que cometer. Não é permitido o anonimato. É assegurado o direito de resposta. A publicação de livros e periódicos não dependerá de licença do Poder Público. Não será, porém, tolerada propaganda de guerra, de processos violentos para subverter a ordem política e social, ou de preconceitos de raça ou de classe. ${ }^{39}$

Entretanto, em 27 de outubro de 1965, após as eleiçôes para governadores de estado, em que a oposição foi vitoriosa em muitos estados importantes (especialmente Israel Pinheiro, em Minas Gerais; e Negrão de Lima, no Rio de Janeiro), o presidente Castelo Branco decretou o Ato Institucional no 2, que, dentre outras disposiçóes, atribuía o predomínio ao Executivo e dissolvia os partidos políticos, tudo justificado em nome dos objetivos da "revolução" e de sua consolidação. ${ }^{40}$

Afora essas determinaçóes, o ato fazia expressa menção a questôes atinentes à imprensa, como, por exemplo, reconsideraçôes quanto ao julgamento e punição de abusos, em relação ao que determinava a Lei no 2.083, de 1953, que regulava a liberdade de imprensa. O art. 12 do AI-2 introduzia uma importante mudança no texto da Constituição de 1946. Onde se lia no art. 141 da Constituição, no parágrafo citado antes: "Não será, porém, tolerada propaganda de guerra, de processos violentos para subverter a ordem política e social, ou de preconceitos de raça ou de classe", ${ }^{41}$ passou a vigorar a seguinte redação: "Não será, porém, tolerada propaganda de guerra, de subversão, da ordem ou de preconceitos de raça ou de classe." ${ }^{2}$ A nuance da alteração está no fato de que a subversão à ordem não prescindiria mais de processos violentos, como ficava explícito no texto anterior. Uma vez que não foi

${ }^{38}$ SMITH, Anne-Marie. Um acordo forçado: o consentimento da imprensa à censura no Brasil, op. cit., p. 33-48.

${ }^{39}$ BRASIL. Constituição (1946). Constituição dos Estados Unidos do Brasil: promulgada em 18 de setembro de 1946.

${ }^{40}$ SMITH, Anne-Marie. Um acordo forçado: o consentimento da imprensa à censura no Brasil, op. cit., p. 37.

${ }^{41}$ BRASIL. Constituição (1946). Constituição dos Estados Unidos do Brasil: promulgada em 18 de setembro de 1946 (grifo nosso).

${ }^{42}$ BRASIL. Ato Institucional n. 2, de 27 de outubro de 1965. 
VIGILANTES DA MORAL E DOS BONS COSTUMES: CONDIÇÓES SOCIAIS E CULTURAIS PARA A ESTRUTURAÇÃO POLÍTICA DA CENSURA DURANTE A DITADURA MILITAR

feito nenhum tipo de especificação quanto ao que seria, de fato, considerado subversivo, tal interpretação passou a ficar a cargo dos que fariam uso da lei. Segundo Alberto Arons de Carvalho, com essa mudança "tanto o empunhar do fuzil quanto o empunhar da caneta, poderiam, indiferentemente, em certos casos, caracterizar 'subversão da ordem'”. ${ }^{3}$

O AI-2 mencionava ainda a situação jurídica dos políticos cassados, e proibia que eles se manifestassem a respeito de assuntos de natureza política. ${ }^{44}$ Essa determinação se tornou ainda mais incisiva quando, por intermédio do Ato Complementar $\mathrm{n}^{\circ} 1$, editado na mesma data, foram estipuladas as penas para os infratores dessa determinaçáo, as quais se estenderiam aos responsáveis pelos órgãos de divulgação, caso a transgressão se desse por meio da imprensa. ${ }^{45}$

Dentro das preocupaçôes do Estado, relativas à salvaguarda dos postulados da revolução e cumprimento das metas de segurança e desenvolvimento, não cabia apenas cercear as opinióes contrárias ou críticas à "revolução", mas também proteger a moral pública e os bons costumes, fundamentais na manutenção da ordem e garantia do bem comum. Essa preocupação, presente tanto na Constituição de 1946, como em vários discursos produzidos pelo regime (por exemplo, a própria Doutrina de Segurança Nacional e Desenvolvimento), se revelava mais explicitamente na Lei no 5.089 de 1967, que proibia a impressão e a circulação de quaisquer publicaçôes destinadas à infância e à adolescência que contivessem ou explorassem temas de crimes, terror ou violência. Os infratores seriam julgados e punidos de acordo com a alínea "E", do art. 9º, da Lei de Imprensa no 2.083, de 1953, que definia o crime de ofensa à moral e aos bons costumes e sua respectiva punição. ${ }^{46}$

O furor legiferante do Estado autoritário resultou em drásticas mudanças na Constituição de 1946, que mesmo alterada não representava "a institucionalização dos ideais e princípios da Revolução". ${ }^{47}$

Assim, pelo Ato Institucional no 4, de 7 de dezembro de 1966, o Congresso foi convocado, em caráter extraordinário, com a finalidade de discutir e votar um projeto de Constituição apresentado pelo presidente da república.

Caso a data prevista pelo texto do ato para que o projeto fosse discutido e votado não fosse cumprida pelos parlamentares, este seria aprovado em sua forma original, o que consistia em uma maneira de pressionar o Congresso para que não fossem propostas muitas emendas ou modificaçôes ao texto original. Isso fica explícito no art. $8^{\circ}$, que dizia: ${ }^{48}$

Art. 8o - No dia 24 de janeiro de 1967, as Mesas da Câmara dos Deputados e do Senado Federal promulgarão a Constituição, segundo a redação final da Comissão, seja a do projeto

\footnotetext{
${ }^{43}$ CARVALHO, Alberto Arons de. A censura e as leis de imprensa. Lisboa: Seara Nova, 1970, p. 133-134.

${ }^{44}$ BRASIL. Ato Institucional n. 2, de 27 de outubro de 1965.

${ }^{45}$ CARVALHO, Alberto Arons de. A censura e as leis de imprensa, op. cit., p.134.

${ }^{46}$ Idem; BRASIL. Lei n. 2.083, de 12 de novembro de 1953.

${ }^{47}$ BRASIL. Ato Institucional n. 4, de 7 de dezembro de 1966.

${ }^{48}$ CARVALHO, Alberto Arons de. A censura e as leis de imprensa, op. cit., p. 135.
} 
VIGILANTES DA MORAL E DOS BONS COSTUMES: CONDIÇÓES SOCIAIS E CULTURAIS PARA A ESTRUTURAÇÃO POLÍTICA DA CENSURA DURANTE A DITADURA MILITAR

Adrianna Cristina Lopes Setemy

com as emendas aprovadas, ou seja o que tenha sido aprovado de acordo com o art. 4º , se nenhuma emenda tiver merecido aprovação, ou se a votação não tiver sido encerrada até o dia 21 de janeiro. ${ }^{49}$

Cumprido o prazo estipulado pelo AI-4, após pouco mais de um mês de trabalho acelerado, foi promulgada, em 24 de janeiro de 1967, a nova Constituição, que passou a vigorar a partir do dia 15 de março de 1967.

No tocante à liberdade de expressão, o $\$ 8^{\circ}$, do art. 150 da nova Constituição fazia a seguinte menção:

$\$ 8^{\circ}$ - É livre a manifestação de pensamento, de convicção política ou filosófica e a prestação de informação sem sujeição à censura, salvo quanto a espetáculos de diversões públicas, respondendo cada um, nos termos da lei, pelos abusos que cometer. É assegurado o direito de resposta. A publicação de livros, jornais e periódicos independe de licença da autoridade. Não será, porém, tolerada a propaganda de guerra, de subversão da ordem ou de preconceitos de raça ou de classe. ${ }^{50}$

A preocupação com a elaboração de um texto que expressasse explicitamente a salvaguarda da liberdade de imprensa é representativo da preocupação dos militares no poder em manter uma fachada legalista que o legitimasse. ${ }^{51}$

Concomitantemente ao envio do projeto para uma nova Constituição, o Congresso recebeu, também do Executivo, um projeto de Lei de Imprensa que visava reformar a que então vigorava desde 1953, para que pudesse atender às necessidades daquele momento.

Nesse caso também, a premência do tempo concedido ao Congresso para estudo e parecer do projeto consistiu em estratégia para que os parlamentares não tivessem tempo de propor reformas durante a tramitação do texto original, que segundo Alberto Arons de Carvalho tinha um aspecto "draconiano". ${ }^{52}$

Mais uma vez o prazo foi cumprido pelo Congresso e, após sensíveis modificações, foi convertido na Lei no 5.250 , de 9 de fevereiro de 1967.

$\mathrm{O}$ primeiro artigo afirma que a lei não visava proibir, mas restringir os abusos da liberdade de imprensa. O texto afirma que náo caberia ao Estado fazer uso da censura para controlar os excessos no trato com a informação. Cada indivíduo seria responsável pelo uso que faria dos meios de comunicação e das informaçóes, devendo cada um estar ciente das puniçóes previstas pela lei:

\footnotetext{
${ }^{49}$ BRASIL. Ato Institucional n. 4, de 7 de dezembro de 1966.

${ }^{50}$ BRASIL. Constituição (1967). Constituição da República Federativa do Brasil: promulgada em 24 de janeiro de 1967.

${ }^{51}$ CARVALHO, Alberto Arons de. A censura e as leis de imprensa, op. cit., p. 135-136.

${ }^{52}$ Ibidem, p. 136.
} 
VigILANTES DA MORAL E DOS BONS COSTUMES: CONDIÇÓES SOCIAIS E CULTURAIS PARA A ESTRUTURAÇÃO POLÍTICA DA CENSURA DURANTE A DITADURA MILITAR

Adrianna Cristina Lopes Setemy

Art. 1ํ - É livre a manifestação do pensamento e a procura, o recebimento e a difusão de informaçóes ou ideias, por qualquer meio, e sem dependência de censura, respondendo cada um, nos termos da lei, pelos abusos que cometer. ${ }^{53}$

Assim como na Constituição de 1967, a nova Lei de Imprensa deixava explícito que, ao contrário das diversóes públicas, a imprensa não estaria sujeita à censura, entretanto, com a ressalva de que poderia ser "legalmente" exercida pelo Estado caso fosse decretado estado de sítio:

$\$ 2^{\underline{o}}$ - O disposto neste artigo não se aplica a espetáculos e diversões públicas, que ficarão sujeitos à censura, na forma da lei, nem na vigência do estado de sítio, quando o Governo poderá exercer a censura sobre os jornais ou periódicos e empresas de radiodifusão e agências noticiosas nas matérias atinentes aos motivos que o determinaram, como também em relação aos executores daquela medida. ${ }^{54}$

Contudo, o art. $2^{\circ}$ da Lei de Imprensa previa a restrição na circulação de periódicos em uma situação específica: caso atentassem à moral e aos bons costumes:

Art. 2o - É livre a publicação e circulação, no território nacional, de livros e de jornais e outros periódicos, salvo se clandestinos (art. 11) ou quando atentem contra a moral e os bons costumes. ${ }^{55}$

Ainda com relação à manutenção da ordem social, da moral e dos bons costumes, o art. 61 fazia a seguinte advertência:

Art. 61 - Estão sujeitos à apreensão os impressos que:

I - contiverem propaganda de guerra ou de preconceitos de raça ou de classe, bem como os que promoverem incitamento à subversão da ordem política e social.

II - ofenderem a moral pública e os bons costumes.

$\$ 1^{\circ}$ A apreensão prevista neste artigo será feita por ordem judicial, a pedido do Ministério Público, que o fundamentará e o instruirá com a representação da autoridade, se houver, e o exemplar do impresso incriminado.

(...)

$\$ 6^{\underline{o}}$ - Nos casos de impressos que ofendam a moral e os bons costumes, poderão os Juízes de Menores, de ofício ou mediante provocação do Ministério Público, determinar a sua apreensão imediata para impedir sua circulação.

Art. 62 - No caso de reincidência da infração prevista no art. 61, inciso II, praticada pelo mesmo

\footnotetext{
${ }^{53}$ BRASIL. Lei n. 5.250, de 9 de fevereiro de 1967.

${ }^{54} \mathrm{Idem}$.

${ }^{55}$ Idem (grifo nosso).
} 
VIGILANTES DA MORAL E DOS BONS COSTUMES: CONDIÇÓES SOCIAIS E CULTURAIS PARA A ESTRUTURAÇÃO POLÍTICA DA CENSURA DURANTE A DITADURA MILITAR

Adrianna Cristina Lopes Setemy

jornal ou periódico, pela mesma empresa, ou por periódicos ou empresas diferentes, mas que tenham o mesmo diretor responsável, o juiz, além da apreensão regulada no art. 61, poderá determinar a suspensão da impressão, circulação ou distribuição do jornal ou periódico. ${ }^{56}$

Embora o texto da nova Lei de Imprensa começasse afirmando a liberdade de expressão, à medida que se desenvolve e se seguem seus parágrafos, vão sendo introduzidas uma série de restriçóes que denunciam seu caráter ambíguo, pois, ao mesmo tempo que o regime garante a liberdade, limita seu alcance. Isso fica evidente, especialmente no capítulo III, que descrevia os abusos no exercício da liberdade de manifestação do pensamento e informação, bem como as respectivas puniçóes para os infratores. ${ }^{57}$

Logo em seguida à promulgação da Lei de Imprensa, foi baixado o Decreto-lei no 314, de 15 de março de 1967, pelo qual entrava em vigor a nova Lei de Segurança Nacional, que introduziu grande parte dos ditames da Doutrina de Segurança Nacional e Desenvolvimento no ordenamento jurídico do país. ${ }^{58}$ A lei passava a abarcar o conteúdo da recente Lei de Imprensa, sem, contudo, revogá-la. Assim, alguns delitos considerados abuso de imprensa passaram para a égide da Lei de Segurança Nacional, e, portanto, a serem julgados pelo foro militar, uma vez que passaram a ser considerados crime contra a segurança nacional.59

Em 13 de dezembro de 1968 foi outorgado o Ato Institucional $n^{\circ}$, que representou um marco na radicalização da repressão, que, contudo, vinha sendo praticada e estruturada desde o golpe de 1964.

Foi a partir do governo do general Médici (1969-1974) que a censura prévia de publicaçôes começou a ser institucionalizada e normatizada. Segundo Douglas Marcelino, em sua pesquisa sobre a censura de livros e diversóes públicas na década de 1970, a atuação do então ministro da Justiça, Alfredo Buzaid (1969-1974), foi fundamental no sentido de aprimorar os mecanismos de controle de publicaçóes, especialmente em função do seu zelo pessoal com a defesa da moral e dos bons costumes, ${ }^{60}$ traduzida na forma do Decreto-lei no 1.077 , de 26 de janeiro de 1970, na Portaria 11-B, de 6 de fevereiro de 1970 e na Instrução nº 1-70, de 24 de fevereiro de 1970, todos de sua autoria, bem como no documento Em defesa da moral e dos bons costumes, publicado também em 1970 pelo Departamento de Imprensa Nacional, no qual ele procurava justificar tanto a necessidade dos diplomas legais que havia elaborado como a sua validade em termos constitucionais. ${ }^{61}$

\footnotetext{
${ }^{56}$ Idem.

${ }^{57}$ Idem.

${ }^{58}$ CALICCHIO, Vera; FLAKSMAN, Dora. Atos Institucionais. Dicionário histórico-biográfico brasileiro. Disponível em: <http://www.cpdoc.fgv.br/dhbb/verbetes_htm/5744_1.asp>. Acesso em: 3 jul. 2017.

${ }^{59}$ CARVALHO, Alberto Arons de. A censura e as leis de imprensa, op. cit., p.140.

${ }^{60}$ MARCELINO, Douglas Átila. Salvando a pátria da pornografia e da subversão: a censura de livros e diversões públicas nos anos 1970. Dissertação (mestrado em História Social) — Programa de Pós-graduação em História Social, Universidade Federal do Rio de Janeiro, Rio de Janeiro, 2006.

${ }^{61}$ BUZAID, Alfredo. Em defesa da moral e dos bons costumes. Brasília: Departamento de Imprensa Nacional, 1970.
} 
VIGILANTES DA MORAL E DOS BONS COSTUMES: CONDIÇÓES SOCIAIS E CULTURAIS PARA A ESTRUTURAÇÃO POLÍTICA DA CENSURA DURANTE A DITADURA MILITAR

Tendo em vista a defesa da família brasileira, da mocidade e da segurança nacional em face à ameaça de um "plano subversivo", ${ }^{62}$ "que insinuava o amor livre para dilacerar as resistências morais da nossa sociedade", o presidente Médici expediu o Decreto-lei no 1.077 , por meio do qual proibia a circulação das publicaçôes contrárias à moral e aos bons costumes e sujeitava as obras provenientes do estrangeiro, destinadas à distribuição ou venda no Brasil, a serem liberadas pelo Departamento de Polícia Federal, que atuaria como o órgáo executor das determinaçôes provenientes do Ministério da Justiça. ${ }^{63}$ Vale lembrar que, até entấo, a Constituição de 1967 e a Lei de Imprensa asseguravam a publicação de livros, jornais e periódicos independentemente de licença da autoridade. Passava a caber ao DPF, quando o Ministério da Justiça julgasse necessário, verificar previamente, em livros e periódicos, a existência de matérias que infringissem a moral e os bons costumes, de acordo com o modo e a forma estipulados na Portaria 11-B, de 6 de fevereiro de 1970. O art. 2 da Portaria conferia aos delegados regionais do DPF a tarefa de proceder ao exame prévio dos livros e periódicos enquadrados pelo Decreto-lei ํㅡㄴ 1.077. Os arts. 5ㅇ, 6o e $10^{\circ}$ da portaria faziam referência ao poder de decisão que era atribuído ao ministro da Justiça, a quem competiria a autoridade de liberar ou vetar publicaçôes que contivessem matéria ofensiva aos padrôes de moralidade, em detrimento do delegado regional do DPF, ao qual caberia o papel de examinar, juntamente com o corpo de funcionários designados para a função, os livros e os periódicos apresentados àquele departamento para verificação prévia, sem, contudo, caber-lhe a tarefa de proibir a divulgação da publicação ou determinar sua apreensão em caso de haver matéria que infringisse o exposto no Decreto-lei no ${ }^{-1.077}$. Nesses casos, conforme determinava a Portaria 11-B, caberia ao delegado regional do DPF comunicar de imediato ao ministro da justiça as conclusões extraídas a partir da sua avaliação do material e apresentar um exemplar da publicação ou cópia do respectivo original, para que entáo o ministro da justiça tomasse as medidas apropriadas. ${ }^{64}$ De acordo com essa estruturação do funcionamento da censura prévia de livros e periódicos, embora o DPF fosse o órgão de execução das solicitaçôes, determinaçóes e decisôes provenientes do ministro da justiça, era a ele, em última instância, que competia o poder de decisão. ${ }^{65}$

\footnotetext{
${ }^{62} \mathrm{O}$ trecho do preâmbulo do Decreto-lei que diz, "CONSIDERANDO que o emprego desses meios de comunicação obedece a um plano subversivo, que pôe em risco a segurança nacional" é expressivo de que a partir do governo Médici, mais especificamente da gestão do ministro Alfredo Buzaid, questóes de segurança nacional e ordem política foram progressivamente sendo acrescentadas aos diplomas legais que regulamentavam a censura de matéria ofensiva à moral e aos bons costumes em publicaçóes. Assim, legitimidade e coerção foram-se mesclando em um mesmo mecanismo que foi sendo instrumentalizado no sentido de atender aos interesses mais especificamente políticos da ditadura. Entretanto, considerando o limite de páginas deste artigo, esse aspecto deverá ser desenvolvido em outro texto.

${ }^{63}$ BRASIL. Decreto-lei n. 1.077, de 26 de janeiro de 1970. Disponível em: <http://www.planalto.gov.br/ ccivil_03/decreto-lei/1965-1988/Del1077.htm>. Acesso em: 27 mar. 2017.

${ }^{64}$ BRASIL. Portaria 11-B, de 6 de fevereiro de 1970, art. 6으.

${ }^{65}$ BRASIL. Portaria 11-B, de 6 de fevereiro de 1970.
} 
VIGILANTES DA MORAL E DOS BONS COSTUMES: CONDIÇÓES SOCIAIS E CULTURAIS PARA A ESTRUTURAÇÃO POLÍTICA DA CENSURA DURANTE A DITADURA MILITAR

Pela Portaria no 219, de 17 de março de 1970, ficavam estabelecidos critérios e procedimentos que os editores e distribuidores deveriam cumprir para que pudessem comercializar suas publicaçóes periódicas destinadas ao público adulto, ilustradas ou não, que contivessem matéria que exteriorizasse manifestação de temas eróticos, de crimes de violência, aventura amorosa, horror ou de humorismo picante. ${ }^{66} \mathrm{~A}$ despeito do Decreto-lei no $1.077,{ }^{67}$ que reafirmava a competência dos juízes de menores e do Ministério Público no que se referia à adoção das medidas previstas na Lei de Imprensa ${ }^{68}$ para impedir a circulação de periódicos que ofendessem a moral pública e os bons costumes, a Portaria estipulava que as publicaçôes periódicas com conteúdo erótico, de crime, horror, aventura amorosa ou humorismo picante só poderiam ser vendidas por intermédio de livrarias, estabelecimentos especializados, bancas de jornais situadas em recintos fechados ou por meio de assinaturas concedidas a maiores de idade, não estando autorizadas, portanto, a ficarem expostas em lugares públicos onde os menores pudessem ter acesso a elas. ${ }^{69}$ Além disso, advertia os adultos de que poderiam ser processados caso facilitassem o acesso de menores às referidas publicações, ${ }^{70}$ considerando que ao Estado cabia o dever de disciplinar a distribuição e a difusão de tais publicaçôes, de maneira a impedir que menores de idade tivessem acesso a elas. ${ }^{71}$

Mais do que propor maneiras de controlar a circulação de livros e periódicos que abordassem questôes consideradas ofensivas à moralidade e aos costumes, os três documentos elaborados pelo ministro da Justiça Alfredo Buzaid, quando vistos em conjunto, evidenciam sua preocupação em estruturar e institucionalizar a prática da censura prévia a esse tipo de publicação por meio dos diplomas legais que foram editados logo em seguida ao Decreto-lei $\mathrm{n}^{\circ} 1.077,{ }^{72}$ ou seja, a Portaria 11-B e a Instrução no $1-70$, de 24 de fevereiro de 1970, alvos de severas críticas por parte de escritores e editores que consideravam o Decreto-lei ㄲo 1.077 uma nova forma de autoritarismo. ${ }^{73}$

No livro Em defesa da moral e dos bons costumes, o ministro da Justiça Alfredo Buzaid procurou reafirmar que o Decreto-lei $n^{\circ} 1.077$ visava apenas às publicaçôes que ferissem valores morais e que, portanto, seu alcance não se estendia às demais publicaçôes..$^{74}$ Referindo-se ao sentido e à abrangência do Decreto-lei, o ministro argumenta que, embora a Constituiçáo garantisse a liberdade de pensamento como um dos direitos fundamentais do indivíduo, em uma época em que o "Estado democrático" tinha de se defender "contra os agentes do comunismo internacional", a Constituição passava a considerar como "inimigos da Pátria" aqueles

\footnotetext{
${ }^{66}$ BRASIL. Portaria n. 219, de 17 de março de 1970, art. $2^{\circ}$.

${ }^{67}$ BRASIL. Decreto-lei n. 1.077, de 26 de janeiro de 1970, arts. 6o e 7․․

${ }^{68}$ BRASIL. Lei de Imprensa n. 5. 250, de 9 de fevereiro de 1970, arts. 61 e 62.

${ }^{69}$ BRASIL. Portaria n. 219, de 17 de março de 1970, art. $2^{\circ}$.

${ }^{70}$ BRASIL. Portaria n. 219, de 17 de março de 1970, art. 3ㅇ.

${ }^{71}$ BRASIL. Portaria n. 219, de 17 de março de 1970, preâmbulo.

${ }^{72}$ BRASIL. Decreto-lei n. 1.077, de 26 de janeiro de 1970.

${ }^{73}$ BUZAID, Alfredo. Em defesa da moral e dos bons costumes, op. cit., p. 28.

${ }^{74}$ Ibidem, p. 41
} 
VIGILANTES DA MORAL E DOS BONS COSTUMES: CONDIÇÕES SOCIAIS E CULTURAIS PARA A ESTRUTURAÇÁO POLÍTICA DA CENSURA DURANTE A DITADURA MILITAR

que promovessem propagandas de guerra, subversão da ordem, preconceito religioso, étnico e de classe, bem como os que fizessem publicaçóes e exteriorizaçóes contrárias à moral e aos bons costumes, que passavam a ser proibidas em nome da segurança nacional. ${ }^{75} \mathrm{O}$ ministro Alfredo Buzaid afirma ainda que o Decreto-lei havia sido editado em cumprimento à última parte do $\$ 8^{\circ}$, do art. 153 da Constituição Federal, ${ }^{76}$ que expressamente declarava intoleráveis as publicaçóes e exteriorizaçóes contrárias à moral e aos bons costumes, no intuito de complementar a censura já antiga de diversóes e espetáculos públicos. $\mathrm{Na}$ opinião do ministro Buzaid, não fazia sentido fiscalizar previamente as diversóes e os espetáculos públicos ao mesmo tempo que eram permitidas "medrarem livremente" publicaçóes "pornográficas". Buzaid considerava legítima a verificação prévia, tanto de diversóes públicas como de livros e periódicos, pois entendia que ao Estado deveria caber o "poder-dever de velar pela moralidade pública e formação sadia da juventude", assim como a tarefa de intervir "em nome dos princípios cristãos, reprovando o ultraje ao decoro e a dissolução da família". ${ }^{77}$

Assim como o mandato do ministro da justiça Alfredo Buzaid (1969-1974) foi marcado por um esforço no sentido de sistematizar e normatizar a censura tanto de diversóes públicas como a de impressos, a gestão de Armando Falcão (1974-1979), ministro da justiça do presidente Geisel, caracterizou-se pela adoção de medidas importantes no sentido de tornar a censura de costumes mais rigorosa e efetiva, não obstante o Brasil estivesse em meio ao chamado "processo de abertura política".

Dentre as medidas adotadas pelo ministro Armando Falcão no sentido de tornar mais rígido o controle sobre a distribuição e circulação de periódicos que tratassem de questóes relativas à moralidade pública e aos bons costumes destaca-se a Portaria no 427, de 25 de maio de 1977, que regulamentava a verificação prévia de publicações vindas do exterior e destinadas à distribuição ou venda no Brasil. A inovação estabelecida por essa portaria é que a verificação dessas publicaçóes passaria a ser feita no próprio local do seu desembarque no Brasil, por funcionários do Departamento de Polícia Federal que seriam designados a prestar seus serviços na Empresa Brasileira de Correios e Telégrafos, nas cidades do Rio de Janeiro, São Paulo, Santos, Campinas, Porto Alegre, Recife, Belém e Manaus, que era por onde chegavam as remessas postais procedentes do estrangeiro. Além da urgência do ministro no sentido de classificar as publicaçóes vindas do exterior antes mesmo que saíssem dos correios, percebe-se que, embora as determinações da portaria estivessem fundamentadas no Decreto-lei no 1.077 , ela estabelecia que as publicaçóes só seriam liberadas se o exame concluísse pela inexistência de matéria "ofensiva à moral e aos bons costumes ou contrária à ordem pública”. Outra Portaria, a de no 319, de 10 de abril de 1979, proibia que essas publi-

\footnotetext{
75 Ibidem, p. 15.

${ }^{76}$ BRASIL. Constituição (1967). Constituição da República Federativa do Brasil, de 24 de janeiro de 1967, art. $150, \$ 8^{\circ}$.

${ }_{77}$ BUZAID, Alfredo. Em defesa da moral e dos bons costumes, op. cit., p. 33.
} 
VIGILANTES DA MORAL E DOS BONS COSTUMES: CONDIÇÓES SOCIAIS E CULTURAIS PARA A ESTRUTURAÇÁO POLÍTICA DA CENSURA DURANTE A DITADURA MILITAR

Adrianna Cristina Lopes Setemy

caçóes fossem expostas e vendidas em bancas de jornal. ${ }^{78}$ Esses exemplos evidenciam que em pleno processo de distensão política, o controle de impressos não apenas continuava sendo realizado como seu alcance continuava sendo sistematicamente ampliado. ${ }^{79}$

Nesse sentido, é preciso relativizar as afirmaçóes de que um dos pontos-chave da abertura política foi o fim da censura de imprensa e o retorno da liberdade de expressão. ${ }^{80}$ Apesar da revogação do AI-5, pela Emenda Constitucional no 11, de dezembro de 1978, a censura de periódicos considerados ofensivos à moral e aos bons costumes continuou a ser praticada até 1980, quando o Poder Judiciário decidiu excluir do regime de verificação prévia as publicaçóes que abordassem temas relacionados ao sexo, à moralidade pública, contrário aos bons costumes ou que apresentassem fotografias de nus, eróticos ou não. ${ }^{81}$ Em 1982, foi publicada a Portaria no 577/82, de 16 de junho, que revogou definitivamente as portarias que regulamentavam a censura prévia de impressos. A partir daquele momento os abusos constatados seriam reprimidos conforme as disposiçôes da Lei de Imprensa $\mathrm{n}^{\circ}$ 5.250, de 9 de fevereiro de 1967, e com a ajuda dos juízes de menores no cumprimento de suas competências quanto à preservação da moralidade pública. A orientação expressa era de que nenhuma apreensão deveria ser executada, a partir de então, por órgãos da Polícia Federal, salvo determinação prévia do ministro da Justiça. Assim, a atuação dos SCDP e da DCDP voltava a se restringir ao campo das diversóes públicas e, quanto aos periódicos e livros considerados de natureza pornográfica, lhes caberia, a partir de então, simplesmente opinar sempre que fossem consultados. ${ }^{82}$ Esses órgáos especializados em matéria de censura continuaram funcionando ativamente mesmo após o fim do regime militar, até que em 1988 a nova Constituição extinguiu definitivamente a DCDP e transferiu para a

\footnotetext{
${ }^{78}$ BRASIL. Portaria n. 319/DG., de 10 de abril de 1979. Arquivo Nacional-Sede em Brasília. Fundo DCDP. Seção: Administração Geral. Série: Correspondência Oficial. Subsérie: Documentos Avulsos.

${ }^{79}$ Durante seu mandato, em meio ao processo de abertura política, Armando Falcão logrou instituir o Conselho Superior de Censura, criado por meio do Decreto n. 83.973, de 13 de setembro de 1979, conforme previsto no art. 15 da Lei n. 5.536, de 21 de novembro de 1969, que regulamentava a censura de obras teatrais e cinematográficas e criava o Conselho Superior de Censura. Instalado em outubro de 1979, o relatório anual da DCDP informava que o Conselho Superior de Censura começou a atuar "com o dinamismo que se esperava do novo órgão" a partir de 1980, quando passou a cumprir uma das suas finalidades precípuas que era a de atuar como órgão normativo do exercício da atividade censória. Em tom otimista, o diretor da DCDP relatava que o novo Conselho havia baixado resoluçóes que puderam, em parte, suprir as necessidades da censura federal decorrentes de uma legislação desatualizada e em descompasso com a realidade. (Cf.. BRASIL. Relatório Anual da DCDP. Data: 5 de janeiro de 1981. Arquivo Nacional-Sede em Brasília. Seção: Administração Geral. Série: Relatório de atividades.)

${ }^{80}$ COUTO, Ronaldo Costa. História indiscreta da ditadura e da abertura. Brasil: 1964-1985. 3. ed. Rio de Janeiro: Record, 1999, p. 167.

${ }^{81}$ BRASIL. Ofício n. 403/82-SE/DCDP. Data: 15 de fevereiro de 1982. Arquivo Nacional-Sede em Brasília. Seção: Administração Geral. Série: Correspondência Oficial. Subsérie: Informações Sigilosas.

82 BRASIL. Ofício-circular n. 85/82-SO/DCDP. Data: 12 de abril de 1982. Arquivo Nacional-Sede em Brasília. Seção: Administração Geral. Série: Correspondência Oficial. Subsérie: Informações Sigilosas. Ver também: BRASIL. Protocolo n. 1627/82-SCCon/DCDP. Data: 15 de julho de 1982. Arquivo Nacional-Sede em Brasília. Seção: Censura Prévia. Série: Publicações. Revista Eros, parecer n. 16, de 1982.
} 
VIGILANTES DA MORAL E DOS BONS COSTUMES: CONDIÇÓES SOCIAIS E CULTURAIS PARA A ESTRUTURAÇÃO POLÍTICA DA CENSURA DURANTE A DITADURA MILITAR

Adrianna Cristina Lopes Setemy

alçada do Ministério da Educação a censura de diversóes públicas, que passou a ter caráter apenas classificatório. ${ }^{83}$

Cabe destacar que, mesmo após a decisão do ministro da justiça de acabar oficialmente com a censura prévia de livros e periódicos, permaneceram as discussões acerca da necessidade de atualizar e incrementar as normas da censura, a fim de "preservar a família brasileira de influências nefastas". Em dezembro de 1981, por exemplo, em meio ao processo de consolidação da abertura política, foi realizado o "Seminário Nacional sobre Programação de TV e Público Usuário”, um evento aberto à sociedade e ao final do qual os participantes preencheram um formulário que tinha em vista obter um "consenso crítico sobre a realização do conclave". Dentre as sugestóes apresentadas pelos participantes destacaram-se a necessidade de aprimorar os mecanismos de censura aos meios de comunicação de massa, incluindo aí os jornais e as revistas, bem como a necessidade de serem realizados outros seminários como aquele, relativo a temas como "O sexo nas comunicaçôes", "A família e a TV", "Filosofia e atuação da censura no Brasil", "Meio de comunicação de massa" e outros. ${ }^{84}$

Daí pode-se depreender que os tradicionais setores da sociedade civil, mais preocupados em proteger a instituição da família e em preservar-lhes os valores da ética e da moral cristã, ainda que em detrimento de liberdades fundamentais, não comemoraram o fim da censura. Ao contrário, parecem ter se sentido órfãos de instituiçóes políticas proibitivas e reguladoras da liberdade de expressão. Vigilantes da moral e dos bons costumes, esses setores mantêm-se, até os dias de hoje, atentos e combativos contra tudo o que entendem ser uma ameaça à família e aos valores morais da sociedade brasileira. Um exemplo é o crescente apoio social a projetos de lei que têm sido apresentados no Congresso Nacional e também nos poderes legislativos estaduais, elaborados a partir do Programa Escola Sem Partido. ${ }^{85}$ O slogan "Por uma lei contra a liberdade de ensinar" ecoa o principal objetivo do programa, que consiste em evitar "doutrinação ideológica" nas instituições de ensino. ${ }^{86} \mathrm{~A}$ história, como ferramenta de ação no presente, permite afirmar a partir da análise

${ }^{83}$ BRASIL. Constituição (1988). Constituição da República Federativa do Brasil, promulgada em 5 de outubro de 1988, art. 21, capítulo II, inciso XVI. Disponível em: <http://www.planalto.gov.br/ccivil_03/ constituicao/constituicao.htm>. Acesso em: 27 março 2017.

${ }^{84}$ BRASIL. Ofício n. 403/82-SE/DCDP. Data: Brasília, 15 de fevereiro de 1982. Arquivo Nacional-Sede em Brasília. Seção: Administração Geral. Série: Correspondência Oficial. Subsérie: Informações Sigilosas.

${ }^{85}$ Essas ideias foram fruto de discussóes realizadas no âmbito do Simpósio A Ditadura Militar e as Artes, coordenado pela Prof. Dra. Miliandre Garcia (UEL), a quem agradeço pela interlocução no que diz respeito ao papel da sociedade na vigilância e censura à liberdade de expressão.

${ }^{86}$ A organizaçáo Escola Sem Partido foi criada em 2004 por membros da sociedade civil, sob a coordenação do advogado Miguel Nagib. Projetos de Lei que propóem a implantação do Programa Escola Sem Partido tramitam em sete estados e no DF, além de vários municípios. O Projeto de Lei no 867/2015 propóe a inclusão do Programa na Lei de Diretrizes e Bases da Educação Nacional. Atualmente, Projetos de Lei que propóem a implantação do Programa Escola sem Partido já foram aprovados em dois municípios: Santa Cruz de Monte Castelo (PR) e Picuí (PB) e também no estado de Alagoas. Cf. PENNA, Fernando. Escola sem Partido como ameaça à educaçáo democrática: fabricando o ódio aos professores e destruindo o potencial educacional da escola. In: MACHADO, Andre Roberto; TOLEDO, Maria Rita de Almeida (Org.). Golpes na história e na escola: o Brasil e a América Latina nos séculos XX e XXI, São Paulo: Cortez: ANPUH SP, 2017. 
apresentada ao longo deste artigo, que em um passado ainda recente setores conservadores da sociedade brasileira estiveram prontos a defender e apoiar o uso legítimo de instrumentos legais de coerção da liberdade de expressão. Mais uma vez a cultura da vigilância à liberdade de expressão estabelece um traço de continuidade entre dois períodos da história política do Brasil: a democracia e a ditadura, cujos resquícios insistem em permear o presente.

Retomando as palavras de Maria Luiza Tucci Carneiro citadas no início do texto, "no decorrer do tempo, as histórias e estórias se repetem", e hoje, novamente, parecem ser temidos os homens de vasta cultura, autores de livros, jornalistas, professores e estudantes. Mas quem os teme? O caso de Millôr Fernandes e, atualmente, a adesão ao Programa Escola Sem Partido indicam que eles incomodam homens e mulheres comuns, parte de setores conservadores da sociedade para quem a militância em defesa de direitos políticos e civis, ou a simples liberdade de expressão, é um defeito e deve ser punido nos rigores da lei. Para Robert Darnton, "Mais que uma prática restrita a uma instituição e seus agentes, a censura é uma força em ação em toda a sociedade". ${ }^{87}$ Portanto, se por um lado é incontestável que o Estado tem sua responsabilidade como estruturador e gerenciador da censura durante a ditadura militar, por outro lado é preciso não esquecer que são muitos os agentes sociais que, ontem e hoje, exigem sançóes contra a livre circulação de ideias. Conhecê-los é fundamental para que possamos compreender o avanço e a manutenção do pensamento autoritário dentro da sociedade brasileira, no passado e ainda no presente.

\section{Referências bibliográficas}

1964-2004: 40 anos do golpe. Ditadura militar e resistência no Brasil. Rio de Janeiro: 7 Letras, 2004.

ALENCAR, Sandra Siebra. A censura versus o teatro de Chico Buarque de Hollanda, 19681978. Acervo, Rio de Janeiro, v. 15, n. 2, p. 101-114, jul./dez. 2002.

ALVES, Maria Helena Moreira. Estado e oposição no Brasil (1964-1984). 2. ed. Petrópolis, Vozes, 1984.

AQUINO, Maria Aparecida de. Censura, imprensa e estado autoritário (1968-1978): o exercício cotidiano da dominação e da resistência: o Estado de São Paulo e Movimento. Bauru: Edusc, 1999.

ARAÚjO, Paulo César de. Eu não sou cachorro, não: música popular cafona e ditadura militar. Rio de Janeiro: Record, 2002.

BERG, Creuza de Oliveira. Mecanismos do silêncio: expressôes artísticas e censura no regime militar (1964-1984). São Carlos: EdUFSCar, 2002.

\footnotetext{
${ }^{87}$ DARNTON, Robert. Censores em ação: como os estados influenciaram a literatura, op. cit., p. 13.
} 
VIGILANTES DA MORAL E DOS BONS COSTUMES: CONDIÇÕES SOCIAIS E CULTURAIS

PARA A ESTRUTURAÇÁO POLÍTICA DA CENSURA DURANTE A DITADURA MILITAR

Adrianna Cristina Lopes Setemy

BUZAID, Alfredo. Em defesa da moral e dos bons costumes. Brasília: Departamento de Imprensa Nacional, 1970.

CALICCHIO, Vera; FLAKSMAN, Dora. Atos Institucionais. Dicionário Histórico-Biográfico Brasileiro. Disponível em: <http://www.cpdoc.fgv.br/dhbb/verbetes_htm/5744_1.asp>.

CAROCHA, Maika Lois. Pelos versos das cançôes: um estudo sobre o funcionamento da censura musical durante a ditadura militar brasileira (1964-1985). Dissertação (mestrado em história) - Instituto de Filosofia e Ciências Sociais, Universidade Federal do Rio de Janeiro, 2007.

"Seu medo é o meu sucesso": Rita Lee, Raul Seixas e a censura musical durante a ditadura militar brasileira. Monografia (graduação em História) — Instituto de Filosofia e Ciências Sociais, Universidade Federal do Rio de Janeiro, 2005

CARNEIRO, Maria Luiza Tucci. Minorias silenciadas: história da censura no Brasil. São Paulo: Edusp/Imprensa Oficial do Estado/Fapesp, 2002.

CARVALHO, Alberto Arons de. A censura e as leis de imprensa. Lisboa: Seara Nova, 1970. CASTRO, Celso; IZECKSOHN, Victor; KRAAY, Hendrik (Orgs.). Nova história militar brasileira. Rio de Janeiro: FGV, 2004.

CODATO, Adriano Nervo; OLIVEIRA, Marcus Roberto de. A marcha, o terço e o livro: catolicismo conservador e ação política na conjuntura do golpe de 1964. Revista Brasileira de História, São Paulo, v. 24, n. 47, p. 271-302, 2004.

CORDEIRO, Janaína. Do golpe de 1964 ao "milagre brasileiro": a campanha da mulher pela democracia (CAMDE). Ação política e imaginário coletivo. Iberoamérica Social: revistared de estudios sociales, número especial, v. 1, p. 49-69, 2016.

COSTA, Cristina. Censura em cena: teatro e censura no Brasil. São Paulo: Edusp/Fapesp/ Imprensa Oficial, 2006.

COSTELLA, Antonio. O controle da informação no Brasil: evolução histórica da legislação brasileira de imprensa. Petrópolis, Vozes: 1970. v 2.

COUTO, Ronaldo Costa. História indiscreta da ditadura e da abertura. Brasil: 1964-1985. 3. ed. Rio de Janeiro: Record, 1999.

D’ARAÚJO, Maria Celina; SOARES, Gláucio Ary Dillon; CASTRO, Celso (Org.). Visões do golpe: a memória militar sobre 1964. Rio de Janeiro: Relume-Dumará, 1994.

DARNTON, Robert. Censores em ação: como os Estados influenciaram a literatura. São Paulo: Companhia das Letras, 2016.

FAGUNDES, Coriolano de Loyola Cabral. Censura e liberdade de expressão. São Paulo: Taika, 1974.

FERES, Sheila Maria. A censura, o censurável, o censurado. Tese (doutorado em Ciência Política) — Fundação Escola de Sociologia e Política, Universidade de São Paulo, 1980. 
VIGILANTES DA MORAL E DOS BONS COSTUMES: CONDIÇÕES SOCIAIS E CULTURAIS PARA A ESTRUTURAÇÁO POLÍTICA DA CENSURA DURANTE A DITADURA MILITAR

FERREIRA, Jorge Luiz; GOMES, Angela Maria de Castro. 1964: o golpe que derrubou um presidente, pôs fim ao regime democrático e instituiu a ditadura no Brasil. Rio de Janeiro: Civilização Brasileira, 2014.

FICO, Carlos. 1968: o ano que terminou mal. In: ARAÚJO, Maria Paula; FICO, Carlos. 1968: 40 anos depois. História e memória. Rio de Janeiro: 7 Letras, 2009, p. 223-239.

A ditadura mostra a sua cara: imagens e memórias do período. 1964-1985. Disponível em: <www.history.umd.edu/HistoryCenter/2004-05/conf/Brazil64/papers/ cficoport.pdf>. p. 35-36.

. A pluralidade das censuras e das propagandas da ditadura. In: 1964-2004: 40 anos do golpe: ditadura militar e resistência no Brasil. Rio de Janeiro: 7 Letras, 2004, p. 71-79.

. Como eles agiam. Os subterrâneos da ditadura militar: espionagem e polícia política. Rio de Janeiro: Record, 2001.

. "Prezada censura": cartas ao regime militar. Revista Topoi, Rio de Janeiro, v. 3, n. 5, p. 251-286, jul./dez. 2002.

. Versōes e controvérsias sobre 1964 e a ditadura militar. Revista Brasileira de História, São Paulo, v. 24, n. 47, 2004.

FILHO, Murilo Melo. O que pensa Castelo. Manchete, Rio de Janeiro, n. 692, p. 18-19, 24 jul. 1965.

FRAGOSO, Heleno. Lei de Segurança Nacional. Dicionário Histórico Biográfico Brasileiro. Disponível em: <http://www.fgv.br/cpdoc/acervo/dicionarios/verbete-tematico/lei-deseguranca-nacional>. Acesso em: 3 jul. 2017.

GARCIA, Miliandre. "Ou vocês mudam ou acabam": teatro e censura na ditadura militar (1964-1985). Tese (doutorado em história social) — Programa de Pós-graduação em História Social, Universidade Federal do Rio de Janeiro, Rio de Janeiro, 2008.

GASPARI, Elio. A ditadura envergonhada. São Paulo: Companhia das Letras, 2002.

GURGEL, José Alfredo Amaral. Segurança e democracia: uma reflexão política sobre a Doutrina da Escola Superior de Guerra. Rio de Janeiro: Editora Biblioteca do Exército/ Livraria José Olympio Editora, 1975, p. 70.

HOBSBAWM, Eric. Era dos extremos. O breve século XX. 1914-1991. 2. ed. São Paulo: Companhia das Letras, 2000.

HOLLANDA, Heloísa Buarque de. Impressóes de viagem: CPC, Vanguarda e desbunde, 1967/70. Rio de Janeiro: Rocco, 1992.

KLEIN, Lúcia; FIGUEIREDO, Marcus. Legitimidade e coação no Brasil pós-64. Rio de Janeiro: Forense Universitária, 1978.

KORNIS, Monica; HEYE, Thomas Ferdinand. TFP. Dicionário histórico-biográfico brasileiro pós-1930. Disponível em: <http://www.fgv.br/cpdoc/acervo/dicionarios/verbete-tematico/ sociedade-brasileira-de-defesa-da-tradicao-familia-e-propriedade>. 
VIGILANTES DA MORAL E DOS BONS COSTUMES: CONDIÇÕES SOCIAIS E CULTURAIS

PARA A ESTRUTURAÇÁO POLÍTICA DA CENSURA DURANTE A DITADURA MILITAR

Adrianna Cristina Lopes Setemy

KUCINSKI, Bernardo. Jornalistas e revolucionários nos tempos da imprensa alternativa. São Paulo: Scritta, 1991.

KUSHNIR, Beatriz. Cães de guarda: jornalistas e censores, do AI-5 à Constituição de 1988. São Paulo: Boitempo Editorial, 2004.

LEVI, Lucio. "Legitimidade". In: BOBBIO, Norberto; MATTEUCCI, Nicola; PASQUINO, Gianfranco. Dicionário de política, 12. ed. Tradução de João Ferreira. Brasília: UNB, 1993.

MARCELINO, Douglas Átila. Para além da moral e dos bons costumes: a censura televisiva no regime militar. Monografia (graduação em História) — Instituto de Filosofia e Ciências Sociais, Universidade Federal do Rio de Janeiro, Rio de Janeiro, 2004.

Salvando a pátria da pornografia e da subversão: a censura de livros e diversôes públicas nos anos 1970. Dissertação (mestrado em História Social) — Programa de Pósgraduação em História Social, Universidade Federal do Rio de Janeiro, Rio de Janeiro, 2006.

MARCONI, Paolo. A censura politica na imprensa brasileira (1968-1978). 2. ed. São Paulo: Global, 1980.

MOBY, Alberto. Sinal fechado: a música popular brasileira sob censura. Rio de Janeiro: Obra Aberta, 1994.

MOTTA, Rodrigo Patto Sá. O anticomunismo militar. In: 1964-2004: 40 anos do golpe. Ditadura militar e resistência no Brasil. Rio de Janeiro: 7 Letras, 2004, p. 292.

. Em guarda contra o perigo vermelho: o anticomunismo no Brasil (1917-1964). Tese (doutorado em História Econômica) — Faculdade de Filosofia, Letras e Ciências Humanas da USP, São Paulo, 2002.

PENNA, Fernando. Escola sem Partido como ameaça à Educação Democrática: fabricando o ódio aos professores e destruindo o potencial educacional da escola. In: MACHADO, Andre Roberto; TOLEDO, Maria Rita de Almeida (Org.). Golpes na história e na escola: o Brasil e a América Latina nos séculos XX e XXI. São Paulo: Cortez/ANPUH-SP, 2017.

Manual Básico da ESG. [S.1.: s.n.], 1976, p. 101.

PEREIRA, Anthony W. Ditadura e repressão: o autoritarismo e o estado de direito no Brasil, no Chile e na Argentina. São Paulo: Paz e Terra, 2010.

PINTO, Leonor Estela Souza. Le Cinema Bresilien Au Risque de La Censure Pendant La Dictature Militaire de 1964 a 1985. Tese (doutorado) — Université de Toulouse — Le Miral, Ecole Supérieure d Audiovisuel, Toulouse, FR, 2001.

PRESOT, Aline. As marchas da Família com Deus pela Liberdade. Dissertação (mestrado) Programa de Pós-graduação em História Social, Univerisade Federal do Rio de Janeiro, Rio de Janeiro, 2004. 
RODRIGUES, Carlos; MONTEIRO, Vicente; GARCIA, Wilson de Queiróz. Censura federal. Brasília: C.R. Editora, 1971.

ROSA, F. A. Miranda. Sociologia do direito: o fenômeno jurídico como fato social. 6. ed. Rio de Janeiro: Zahar, 1978.

SETEMY, Adrianna Cristina Lopes. "Em defesa da moral e dos bons costumes": censura de periódicos no regime militar. Rio de Janeiro: UFRJ/PPGHIS, 2008.

SILVA, Deonísio da. Nos bastidores da censura: sexualidade, literatura e repressão pós-64. São Paulo: Estação Liberdade, 1989.

SIMÓES, Inimá. Roteiro da intolerância: a censura cinematográfica no Brasil. São Paulo: Senac São Paulo, 1999.

SIMÓES, Solange de Deus. Deus, pátria e família: as mulheres no golpe de 64. Belo Horizonte: UFMG, 1983.

SMITH, Anne-Marie. Um acordo forçado: o consentimento da imprensa à censura no Brasil. Rio de Janeiro: FGV, 2000.

SOARES, Gláucio Ary Dillon. A censura durante o regime autoritário. Revista Brasileira de Ciências Sociais, São Paulo, v. 4, n. 10, p. 21-43, jun. 1989.

STEPHANOU, Alexandre Ayub. Censura no regime militar e militarização das artes. Porto Alegre: EdiPUCRS, 2001.

- O procedimento racional e técnico da censura federal brasileira como órgão público: um processo de modernização burocrática e seus impedimentos (1964-1988). Tese (doutorado em História) — Pontifícia Universidade Católica do Rio Grande do Sul, Porto Alegre, 2004.

\section{Como citar}

SETEMY, Adrianna Cristina Lopes. Vigilantes da moral e dos bons costumes: as condiçôes sociais e culturais para a estruturação política da censura durante a ditadura militar. Topoi. Revista de História, Rio de Janeiro, v. 19, n. 37, p. 171-197, jan./abr. 2018. Disponível em: $<$ www.revistatopoi.org $>$. 